\title{
Impact of COVID-19 on Education and Internships of Hospitality Students
}

\section{IJCRR}

Section: Healthcare

Sci. Journal Impact

Factor: 6.1 (2018)

ICV: 90.90 (2018)

(c) (i) (8)

Copyright@IJCRR

\section{Rakesh Dani' ${ }^{1}$, Ravish Kukreti ${ }^{2}$, Anket Negi ${ }^{3}$, Deepak Kholiya ${ }^{4}$}

'Assistant Professor, Department of Hospitality Management, Graphic Era Deemed to be University, Bell Road, Dehradun, India; ${ }^{2}$ Research Scholar, Department of Hospitality Management, Graphic Era Deemed to be University, Bell Road Dehradun, India; ${ }^{3}$ MHM III Semester, Department of Hospitality Management, Graphic Era Deemed to be University, Dehradun, India; ${ }^{4}$ Associate Professor, Department of Agriculture, Graphic Era Hill University, Dehradun, India.

\section{ABSTRACT}

Introduction: As we all know COVID-19 pandemic became a problem all over the world. Every country is trying to fight with this pandemic virus, due to which many countries announced complete lockdown in their country. Schools/ colleges help in developing social skills and awareness of students which is interrupted because of lockdown due to COVID-19. Not only studies are affected but it has also affected the industrial training of the students. Hospitality students must have good communication skills, social values, teamwork and many more qualities .which are affected due to pandemic which can't be learned through online classes. Many of the students were not able to attend online classes because of the poor network in their region, loss of focus and interest, some time does not get much space in their home for online studies due to more members in the family, sometimes they don't have a system to excess online classes. Internships of Hospitality students were affected as their internship programmes were either reduced or cancelled due to this pandemic.

Objectives: The primary objective of this research is to find out the impact of this pandemic on education and internships of hospitality students.

Methods: This research paper has derived conclusions based on the feedback of different hospitality colleges situated in Dehradun. The feedback was based on some questionnaires which were asked through an online survey. The feedback is collected on percentage bases which are then analyzed for getting results and conclusion.

Results: According to the results $97 \%$ of hospitality students agreed that their Internship programmes are badly affected due to this pandemic and they face various problems during online classes.73\% of students disagreed when asked will they prefer online mode of education even post this Pandemic.75\% students agreed that they got full support from their teachers during online classes.

Conclusion: Most of the students were facing various problems in their online classes, their internship programmes is effected, because of which their learning and skill development activities are effected but the good thing is that most of the student was getting full support from their teachers/colleges/ Universities and most of the students find the online mode of education as a better and useful tool for online studies during this pandemic. But still, most of the students prefer traditional (face to face) mode of education over the online mode of education.

Key Words: Internship, Covid-19, Hospitality

\section{INTRODUCTION}

This year (2019-20) because of the outbreak of COVID-19 many things changes all over the world. COVID-19 also known as Coronavirus disease is first identified in Wuhan China (December 2019). Due to this infectious pandemic virus, every country all over the world put complete lockdown in their countries which affect the economy of that country (closing of the hospitality sector and education sectors com- pletely) which has a very bad impact on hospitality sectors. The hospitality industry is a service industry which includes many other sectors like hotels, restaurants, tourism, transportation and many more sectors. ${ }^{1}$ Due to this pandemic education sector went through many changes which have a great impact on Students, Teachers and educational institutes. ${ }^{1}$ Because of government guideline and lockdown to control pandemic spread. Because of problems caused by lockdown many students make changes in their education plans. Even

\section{Corresponding Author:}

Dr. Rakesh Dani, Assistant Professor, Department of Hospitality Management, Graphic Era Deemed to be University, Bell Road, Dehradun, India; Email: rakeshdanipchm@gmail.com

ISSN: 2231-2196 (Print)

Received: 24.08 .2020
ISSN: 0975-5241 (Online)

Revised: 28.09 .2020
Accepted: 20.10 .2020 
in India $47.46 \%$ of students who want to study in abroad changed or reconstructed there higher education plans ${ }^{2}$. Not only education is effecting but the overall growth of students is also affecting. Due to pandemic mental stress is also developing on students the rate of depression amongst students has increased since the start of the pandemic this is According to a survey done on 18,000 college students by ${ }^{3}$. Hospitality sector student's physical and mental health is one of the most important parts for them to work in this sector. Students of hospitality sectors have to go through industrial training for which they must be healthy and mentally strong. ${ }^{3}$

All students from every field are affected due to this virus. Finding of the effect of COVID-19 on studies of Hospitality students, all their theory and practical studies were affected. .In hotel studies there are mainly four subjects Food production, Food and beverage service, Front office, and Accommodation operation in these subjects students should have more practical knowledge, which can only be developed through more and more practical's of that subject. Food production students having good knowledge of recipes but lack in practical knowledge of making that recipe without knowing its technique and science and proper way of cooking is of no use, without doing the work practically the student will not be able to find his/her area of improvements while cooking and it will also affect their problem-solving skills. The curriculum of the hotel management is much more practical and industry-oriented and these curriculums are more suited for on-campus learning. ${ }^{4}$ The practical work which is one of the most important parts of this field, which is necessary for every student of this field for increasing their skills, and for overall growth, is seriously affected. There is still a global skills shortage in the hospitality sector and this shortage will continue over next few years mostly the practical work which is one of the most important parts of this field, which is necessary forever students of this field for increasing their skills, and for overall growth, is seriously affected. Many exams and assignments were cancelled or done online; some institutes shifted their exam dates. Many students in their final years were affected due to interruption in teaching because of COVID-19 pandemic. Industrial training which is one of the biggest exposures for every student, where they learn about the work and the industry is postponed or stopped due to this problem. Hospitality students during their internship learn work from there seniors and supervisors, for excellent and for good learning supervisors during internship should share their experience and learning with intern students to make their learning more interesting but due to COVID-19, it's not possible in the current situation. As well as many training, internship programmes are cancelled due to this pandemic and most of the universities shifted towards online internship programmes, but this is not possible for hospitality students to take an online internship because in this sector the value of communication skills, social skills and practical knowledge is required more than any other field, which can only be learned by interacting with more and more guest in hotels and by understanding the working environment of the hospitality sector and all these learning and developing process of students is affected due to this pandemic. ${ }^{5}$

As we known because of COVID -19 pandemic all schools, colleges and Universities were close, effecting studies of students. Nowadays mostly every university shifted towards online mode for providing regular classes and for taking exam of student's. But still, there is a lot of students who were not able to attend classes due to lack of network, economically weak or many more reasons. Many students stated that they don't have any prior experience and knowledge engaging with online/distance learning before this pandemic ${ }^{4}$. Not only that but due to the late exams because of COVID-19 their results were also late due to which entire Admission systems of institutes is affected due to which many students are having problems in getting admission and in choosing a correct institution for their higher education. Many students changed their education plans for higher studies. In this, we will find out problems faced by students, what they think about online methods for studying. The data of this research is collected on the bases of feedback from different hospitality colleges students situated in Dehradun. The main objective of this research is to find out the impact of COVID-19 on education and internships of hospitality students, to know how this pandemic is affecting them and what problems they are facing with the online mode of education. ${ }^{6,7}$

\section{REVIEW OF LITERATURE}

\begin{tabular}{|c|c|c|c|}
\hline S. No & Resource person & Year of Publication & Findings \\
\hline 1. & Shivangi Dhawan.$^{5}$ & 2020 & $\begin{array}{l}\text { A natural disaster like COVID } 19 \text { affects the education of } \\
\text { students due to closure of all education institutes which } \\
\text { create problem in the learning of students. } \\
\text { Many institutes start adopting e-learning tools for provid- } \\
\text { ing education and learning to students online. } \\
\text { To make e-learning better and effective during such disas- } \\
\text { ter we need to learn and focus on the use of technology in } \\
\text { a more effective way. }\end{array}$ \\
\hline
\end{tabular}




S. No Resource person Year of Publication Findings

2. $\quad 2020$ Linda Hoxha. ${ }^{4}$

2020

Pravin Kumar Patel, Shivali Kharoliwal, Jaya Sharma and Prashant Khemariya. ${ }^{7}$ Seaman. ${ }^{11}$
Due to this pandemic, various activities like admissions processes, competitive exams, many entrance exams for higher education is postponed or cancelled which create problems for students.

The main challenge of providing education and learning is solved with the online learning method. Virtual platforms, eBooks and online sources are provided to students to enhance better and flexible education.

Students found it difficult to pay attention during online learning it may be due to many reasons like Distraction, the overload of assignments, Doubts and concern about their results, lack of organization, time management is the hindrance in the learning process.

Impact of this pandemic is very bad on Indian tourism and hospitality sectors. According to the Ministry of Civil Aviation, our country faces a drop of nearly $25 \%$ to $30 \%$ international visitors. Its impact is also seen on domestic tourism in our country Nearly 40\% drop has been recorded in summer destinations Regions like Leh, Guwahati, Srinagar and Amritsar

The internship provides students learning beyond classrooms and helps them in learning more about the hotel. Supervisors should communicate, share their experience and learning with intern students which will make their learning during internship more exciting and interesting.

The education sector in India is going to witness major growth in upcoming years, because of digital empowerment.

Disasters can create problems in the lives of people. Students and Teachers face many problems due to this like Stress, lack of concentration, focus and many other problems.

According to them, the nowadays online education system is progressing very fast in the higher education system. And the online system is also compared with the hypothetical system known as "Ideal education system".

According to their survey, 50\% of the hospitality students agreed that face to face delivery is more effective than online learning.

Their survey also showed that nearly $80 \%$ of hospitality administrators agreed in favour of face to face education is better over online education.

During the practical period, the students had the opportunity to train their skills and to acquire more experience. Students concentrate more on those issues during their studies that were important from a practical point of view.

\section{OBJECTIVES}

After the review of existing literature and present scenario following objectives for the research were framed

1. To analyse the impact of Covid-19 on the academic studies of Hotel Management Students

2. To examine the impact of Covid -19 on Industrial training of Hotel management students

\section{RESEARCH METHODOLOGY}

The research is based on primary data as well as on secondary data. The secondary data includes various internet sources, journals articles, and some news articles. The primary data is collected based on various questionnaires asked from hospitality students through a survey (main region Dehradun). Based on which primary data collection and analysis was done ( Fig 1 and 2). 
DATA ANALYSIS

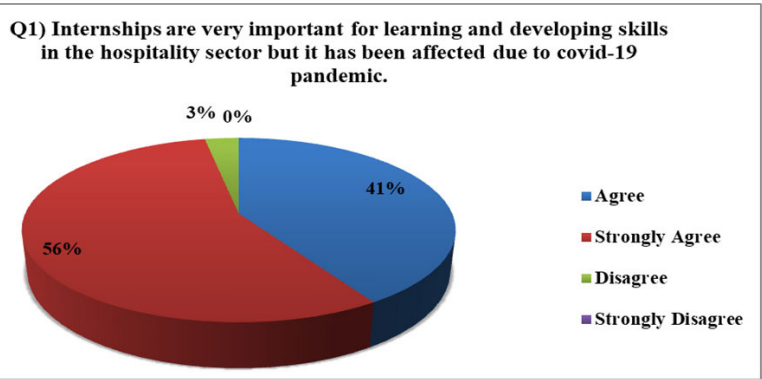

Figure 1: Importance of Internship and effect of Pandemic.

Q2) Online mode of education is better than traditional (face to face) method of education

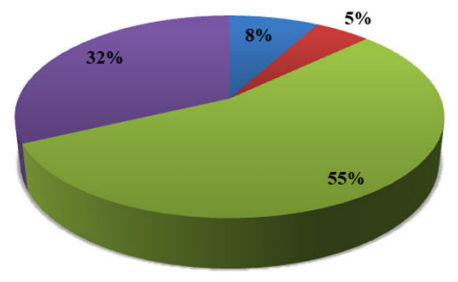

- Agree

- Strongly Agree

- Disagree

- Strongly Disagree

Figure 2: Online Vs Traditional Education.

Q3) During this pandemic "online mode of education has "become a very useful and important tool for education

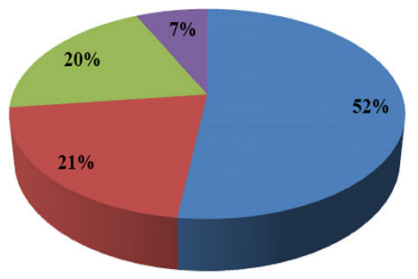

- Agree

- Strongly Agree

- Disagree

- Strongly Disagree

Figure 3: Online mode as important tool during Pandemic.

Q4) During online classes students are getting Full support from their universities and from their teachers.

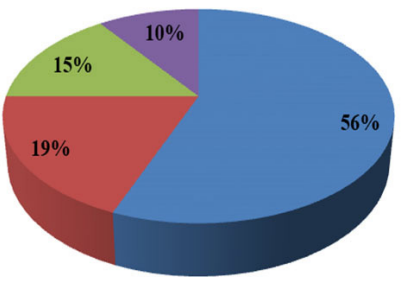

- Aglee

- Strongly Agree

- Disagree

n Strongly Disagree

Figure 4: Teachers support during online classes.
Q5)Most students are experiencing various problems during online classes, such as network problem, lack of attention, lack of interest and

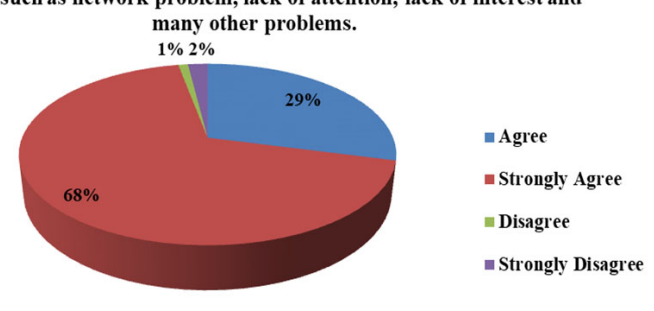

Figure 5: Problems faced during online classes.

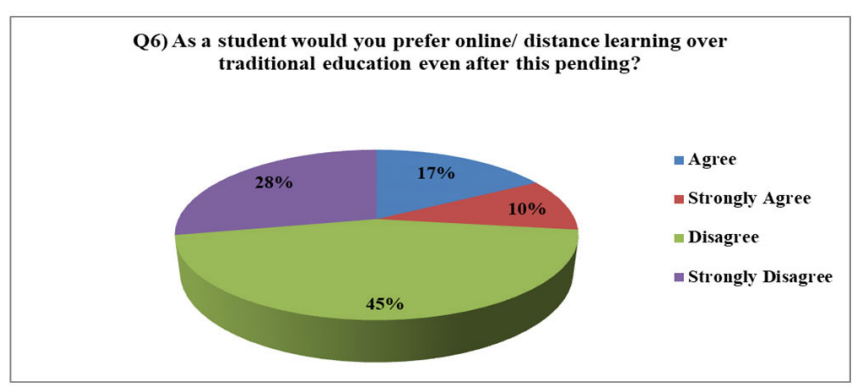

Figure 6: Prefer online or traditional education mode.

Q7) Students of hospitality sector will also be affected due to the impact of covid-19 on the hospitality industry?

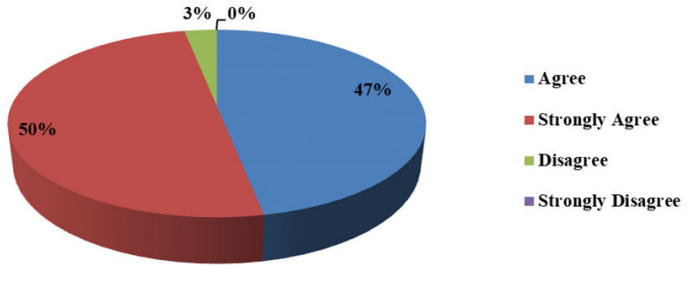

Figure 7: Covid effect on the Hospitality industry.

\section{FINDINGS AND CONCLUSION}

Based on the survey which was conducted on hospitality students, to know the impact of COVID-19 on them and how it affects them in various ways we found the results which are as follows:

1. According to survey data, $97 \%$ of hospitality students agreed that their Internship programmes are badly affected due to this pandemic, because of which their learning and skill development activities are severely affected. Figure-1

2. Moreover, nearly $97 \%$ of hospitality students agreed on the fact that the hospitality industry is severely affected due to this pandemic and it will affect all the students related to the hospitality sector.Figure-7 
3. The result of the study stated that majority of the students were happy with the online version of education during the tenure of this pandemic, $73 \%$ students find the online mode of education very useful during this pandemic for their studies Figure 3, Moreover, nearly $73 \%$ students disagreed when asked will they prefer online mode of education even post this Pandemic. Figure- 6

4. About $97 \%$ of students agreed that they sometimes face various technical issues during online classes such as network problem and noise interruptions etc. Figure- 5 Majority of students nearly $75 \%$ of students were agreed that they got full support during online classes from there universities/colleges and teachers. Figure-4.

\section{REFERENCES}

1. Kukreti.R, Dani. K. Analyzing Role of University/Institute Support and Organizational Environment in Industrial Training Satisfaction of Hospitality Students: concerning Uttarakhand. International Journal of Recent Technology and Engineering.2020;8(6):549-554.

2. Ashwani .A., Placements of industry freshers: Impact Due To COVID-19, Available from http://bweducation.businessworld. in/article/Placement-Of-Industry-Freshers-Impact-Due-ToCOVID-19.

3. Shyna Kalra. COVID-19 impacts hospitality, travel sectors: What's on the plate for students, job aspirant.2020. Available from: http//indianexpress.com/article/education/whats-on-plate- for-graduates-and-aspirants-of-hospitality-travel-the-worst-hitindustry-6395229.

4. Duraku ZH, Hoxha N. The impact of COVID-19, school closure, and social isolation on gifted students' wellbeing and attitudes toward remote (online) learning.2020. Available from DOI: 10.13140/RG.2.2.23967.38567/1

5. Dhawan S. Online learning: A panacea in the time of COVID-19 crisis. Journal of Educational Technology Systems. 2020 Sep; 49(1):5-22.

6. Jena .P. Impact of Covid-19 on higher education in India. International Journal of Advanced Education and Research: 2020;5(3):77-81

7. Patel PK, Sharma J, Kharoliwal S, Khemariya P. The Effects of Nobel Corona Virus (Covid-19) in the Tourism Industry in India. International Journal of Engineering Research \& Technology (IJERT).2020; 9(5):780-788.

8. Zahoor Ahmad Lone. Impact of Online Education in India. International Journal of Engineering Science and Computing(IJESC). 2017 July 1;7(7):13950-13953.

9. Di Pietro G. The academic impact of natural disasters: evidence from L'Aquila earthquake. Education in Economics. 2018 Jan 2;26(1):62-77.

10. Aithal PS, Aithal S. Impact of on-line education on higher education system. International Journal of Engineering Research and Modern Education (IJERME). 2016 Aug 30;1(1):225-35.

11. Sciarini M, Beck J, Seaman J. Online learning in hospitality and tourism higher education worldwide: A descriptive report as of January 2012. Journal of Hospitality \& Tourism Education. 2012 Apr 1;24(2-3):41-4.

12. Katajavuori N, Lindblom-Ylänne S, Hirvonen J. The significance of practical training in linking theoretical studies with practice. Higher Education. 2006 Apr 1;51(3):439-64. 